\title{
Paenibacillus favisporus sp. nov., a xylanolytic bacterium isolated from cow faeces
}

Correspondence

Encarna Velázquez evp@gugu.usal.es

\author{
Encarna Velázquez, ${ }^{1}$ Trinidad de Miguel, ${ }^{2}$ Margarita Poza, ${ }^{2}$ Raúl Rivas, ${ }^{1}$ \\ Ramón Rosselló-Mora ${ }^{3}$ and Tomás G. Villa²
}

\author{
${ }^{1}$ Departamento de Microbiología y Genetica, Facultad de Farmacia, Universidad de Salamanca, \\ Spain \\ ${ }^{2}$ Departamento de Microbioloxía e Parasitoloxía, Facultad de Farmacia, Universidad Santiago de \\ Compostela, Spain \\ ${ }^{3}$ Institut Mediterrani d'Estudis Avancats and Departamento de Biologia Ambiental, Universitat \\ de les Illes Balears (CSIC-UIB), Crtra Valldemossa Km 7·5, 07071 Palma de Mallorca, Spain
}

\begin{abstract}
During a search for xylan-degrading micro-organisms, a sporulated bacterium was recovered from recent and old cow dung and rectal samples. The isolates were identified as members of a novel species of the genus Paenibacillus, based on 16S rRNA gene sequences. According to the results of phylogenetic analysis, the most closely related species was Paenibacillus azoreducens. Phenotypic and chemotaxonomic analyses and DNA-DNA hybridization experiments also showed that the isolates belonged to a novel species of the genus Paenibacillus. The novel species is a facultatively anaerobic, motile, Gram-variable, sporulated rod. The spores of this rod-shaped micro-organism occur in slightly swollen sporangia and are honeycomb-shaped. The main fatty acid is anteiso-branched $\mathrm{C}_{15: 0}$. Growth was observed with many carbohydrates, including xylan, as the only carbon source and gas production was not observed from glucose. The novel species produces a wide variety of hydrolytic enzymes, such as xylanases, cellulases, amylases, gelatinase, urease and $\beta$-galactosidase. On the contrary, it does not produce caseinase, phenylalanine deaminase or lysine decarboxylase. According to the data obtained in this work, the strains belong to a novel species, for which the name Paenibacillus favisporus sp. nov. is

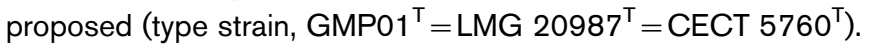

Xylan is a heterogeneous polymer that is composed of $(1,4)$ linked $\beta$-D-xylosyl residues. It is very abundant in nature, being the major component of hemicelluloses in monocotyledon cell walls. Xylanases (1,4- $\beta$-D-xylanohydrolases) are a group of xylanolytic enzymes that hydrolyse xylan to xylan-oligosaccharides and xylose; such degradation of xylan is industrially important in diverse fields, such as enzyme-aided bleaching of paper (Viikari et al., 1994), production of fuels or chemicals such as ethanol or lactate from plant biomass (Lamed et al., 1988), animal feed additives (Annison, 1992), bread-making (Maat et al., 1992) and, in combination with pectinase and cellulase, in degumming of plant fibre sources (Puchart et al., 1999). Several micro-organisms have been described as xylanase producers; many of these belong to the Gram-positive bacteria within the actinomycetes (Ruiz-Arribas et al., 1995; Busch \& Stutzenberger, 1997; Beg et al., 2000; Chamberlain

The GenBank/EMBL/DDBJ accession number for the $16 \mathrm{~S}$ rRNA gene sequence of strain $\mathrm{GMPO}^{\top}$ is $\mathrm{AY} 208751$.

Micrographs and an expanded phylogenetic tree are available as supplementary material in IJSEM Online.
\& Crawford, 2000; Rivas et al., 2003a) and bacilli (Tabernero et al., 1995; Nishimoto et al., 2002; Sá-Pereira et al., 2002; Tseng et al., 2002).

The bacilli are a wide group of micro-organisms that are characterized by endospore formation. Currently, this group includes several families and genera, many of which belonged to the former genus Bacillus, which has been separated into several novel genera that belong to several families. This is the case for the genus Paenibacillus, which was proposed by Ash et al. (1994) and belongs to the family 'Paenibacillaceae'. Members of the genus Paenibacillus are facultatively anaerobic organisms that produce spores in swollen sporangia and have DNA G $+\mathrm{C}$ contents that range from 45 to $54 \mathrm{~mol} \%$. Some of these bacteria excrete diverse assortments of extracellular polysaccharidehydrolysing enzymes, including xylanases (Zamost et al., 1991; Morales et al., 1995; Hespell, 1996; Aÿ et al., 1998; Nielsen \& Sorensen, 1997; Lee et al., 2000).

Taking into account the fact that xylan is a polysaccharide that is present in plant cell walls, we searched for xylanhydrolysing bacteria in the faeces of ruminant animals. In 
the present work, we describe the isolation and identification of a novel xylan-degrading species of the genus Paenibacillus.

Isolation of strains was always done in YNBX medium that contained xylan as the carbon source $(6.7 \mathrm{~g}$ yeast nitrogen base $\mathrm{l}^{-1}, 7 \mathrm{~g}$ xylan $\mathrm{l}^{-1}$ and $20 \mathrm{~g}$ agar $\left.\mathrm{l}^{-1}\right)$, as specified by Esteban et al. (1983). The three strains from this study were isolated from old $\left(\mathrm{GMP} 01^{\mathrm{T}}=\mathrm{USC} 13^{\mathrm{T}}\right)$ and recent $($ GMP02 $=$ USC14) cow dung in Salamanca, Spain, and from rectal samples $(\mathrm{GMP} 03=\mathrm{USC} 15)$ of a cow in León, Spain. Routine growth of all strains was done in tryptic soy broth and, unless otherwise stated, the temperature for both growth and biochemical tests was $37^{\circ} \mathrm{C}$. Cultures in liquid medium were carried out routinely at $37^{\circ} \mathrm{C}$ in a rotary shaker at 250 r.p.m. The three colonies were of an aqueous aspect, translucent, rounded and convex. As they aged, a brown spot could be observed at the centre of the colony. The three strains were isolated on YNBX plates and showed a high xylanolytic activity.

Strain $\mathrm{GMP}^{\mathrm{T}} \mathrm{1}^{\mathrm{T}}$ was grown in YNBX medium for $48 \mathrm{~h}$ to check for motility by phase-contrast microscopy. Cells were also stained according to the classical Gram procedure described by Doetsch (1981). For electron microscopy, cells were grown in liquid YED (yeast extract/ glucose) medium for 3 days at 180 r.p.m. and $28^{\circ} \mathrm{C}$. Samples were fixed overnight in $2 \%(\mathrm{v} / \mathrm{v})$ glutaraldehyde. Sections were mounted according to Reynolds (1963) and examined with a Philips EM 300 electron microscope. For scanning microscopy, cells and spores were treated with $2 \%$ uranyl acetate and observed under a Philips PSEM 500 electron microscope. Cells of strain GMP01 ${ }^{\mathrm{T}}$ are straight, rod-shaped and generally observed singly, but can also occur as a group of 3-4 cells in a chain-like structure. Actively growing cells had a mean length of $2-3 \mu \mathrm{m}$ and a mean width of $0.5-0.7 \mu \mathrm{m}$. They are Gram-variable and exhibit motility by polar and subpolar flagella, frequently at both poles. The organism is sporulated and its spores are resistant to dry heat (the number of viable cells does not vary when treated at $150{ }^{\circ} \mathrm{C}$ for $10 \mathrm{~min}$ ). Spores are easily stained with Gram-stain. They are central or centralterminal, $1 \mu \mathrm{m}$ long and $0.7 \mu \mathrm{m}$ wide and slightly distend the sporangium wall. When observed by scanning electron microscopy, the spore surface resembles a honeycomb and according to the thin sections visualized by transmission electron microscopy, they exhibit a star-shape morphology (see Figs A and B, available as supplementary material in IJSEM Online).

For 16S rDNA sequencing, DNA extraction was carried out as described previously (Rivas et al., 2001). Amplification and sequencing of $16 \mathrm{~S}$ rDNA were performed according to a method described previously (Rivas et al., 2003a). The sequence obtained was compared with those from GenBank by using the FASTA program (Pearson \& Lipman, 1988). Sequences were aligned by using CLUSTAL $\mathrm{W}$ software (Thompson et al., 1997). Distances were calculated according to the method of Kimura (1980). Phylogenetic trees were inferred by using the neighbour-joining method (Saitou \& Nei, 1987). Bootstrap analysis was based on 1000 resamplings. The MEGA 2.1.0 package (Kumar et al., 2001) was used for all analyses. Trees were rooted by using Lactobacillus delbrueckii subsp. lactis DSM $20072^{\mathrm{T}}$ as the outgroup.

The complete $16 \mathrm{~S}$ rDNA sequence of isolate GMP01 ${ }^{\mathrm{T}}$ (GenBank accession no. AY208751) was obtained. The complete sequences of strains GMP02 (AF346495) and GMP03 (AY308758) had $100 \%$ similarity to that of GMP01 ${ }^{\mathrm{T}}$. Comparison against $16 \mathrm{~S}$ rRNA gene sequences held in GenBank indicates that the organism is related phylogenetically to members of the family 'Paenibacillaceae'. Fig. 1 shows the phylogenetic tree obtained by the neighbour-joining method (an expanded tree is available as supplementary material in IJSEM Online). The most closely related species is Paenibacillus azoreducens, with $97 \cdot 7 \%$ sequence similarity. Therefore, DNA-DNA hybridization was performed with the type strain of this species.

Phenotypic characterization was performed according to the standard methods described by Logan \& Berkeley (1984) and Claus \& Berkeley (1986), using P. azoreducens DSM $13822^{\mathrm{T}}$ as the reference. Cellulases were detected after 7 days incubation on plates that contained $0.5 \% \mathrm{CM}$ cellulose as the carbon source, $0 \cdot 3 \%$ yeast extract and $1 \cdot 5 \%$ agar. Plates were stained with $1 \%$ Congo red solution in water. Other physiological and biochemical tests were done by using the API 20E system (bioMérieux), following the manufacturer's instructions. For testing natural antibiotic resistance, the following antibiotics were used: erythromycin $(15 \mu \mathrm{g})$, penicillin $(10 \mu \mathrm{g})$, cephalexin $(30 \mu \mathrm{g})$, oxacillin $(5 \mu \mathrm{g})$, bacitracin $(10 \mu \mathrm{g})$, piperacillin $(100 \mu \mathrm{g})$, tobramycin $(10 \mu \mathrm{g})$, gentamicin $(10 \mu \mathrm{g})$, cefoxitin $(30 \mu \mathrm{g})$ and dibekacin $(10 \mu \mathrm{g})$. Discs that contained each antibiotic were placed onto plates with antibiotic medium 1 agar (Difco) that had previously been inoculated with the appropriate strain. According to the data obtained, the three strains showed the same phenotypic characteristics. Table 1 shows the phenotypic properties of the novel species, as well as those of the most closely related species in the genus Paenibacillus. Strains of the novel species are different from phylogenetically related species in anaerobic growth, oxidase, nitrate reduction, growth at $50^{\circ} \mathrm{C}$ and fermentation of glucose and L-arabinose (Table 1).

Analysis of cellular hydroxy fatty acids was performed from a culture of strain GMP01 ${ }^{\mathrm{T}}$ grown for $24 \mathrm{~h}$ in TSA medium (Merck) at $28^{\circ} \mathrm{C}$, as described previously (Rivas et al., 2003b). Results of the chemotaxonomic analyses are shown in Table 2. According to published data, the cellular fatty acid pattern of strain $\mathrm{GMP} 01^{\mathrm{T}}$ is similar to those of phylogenetically closely related species of the genus Paenibacillus. The main fatty acid is anteisobranched $\mathrm{C}_{15: 0}$, which comprises $48 \cdot 8 \%$ of the total. This value is lower than those reported for other species of Paenibacillus, but higher than that reported for $P$. azoreducens (Meehan et al., 2001). 


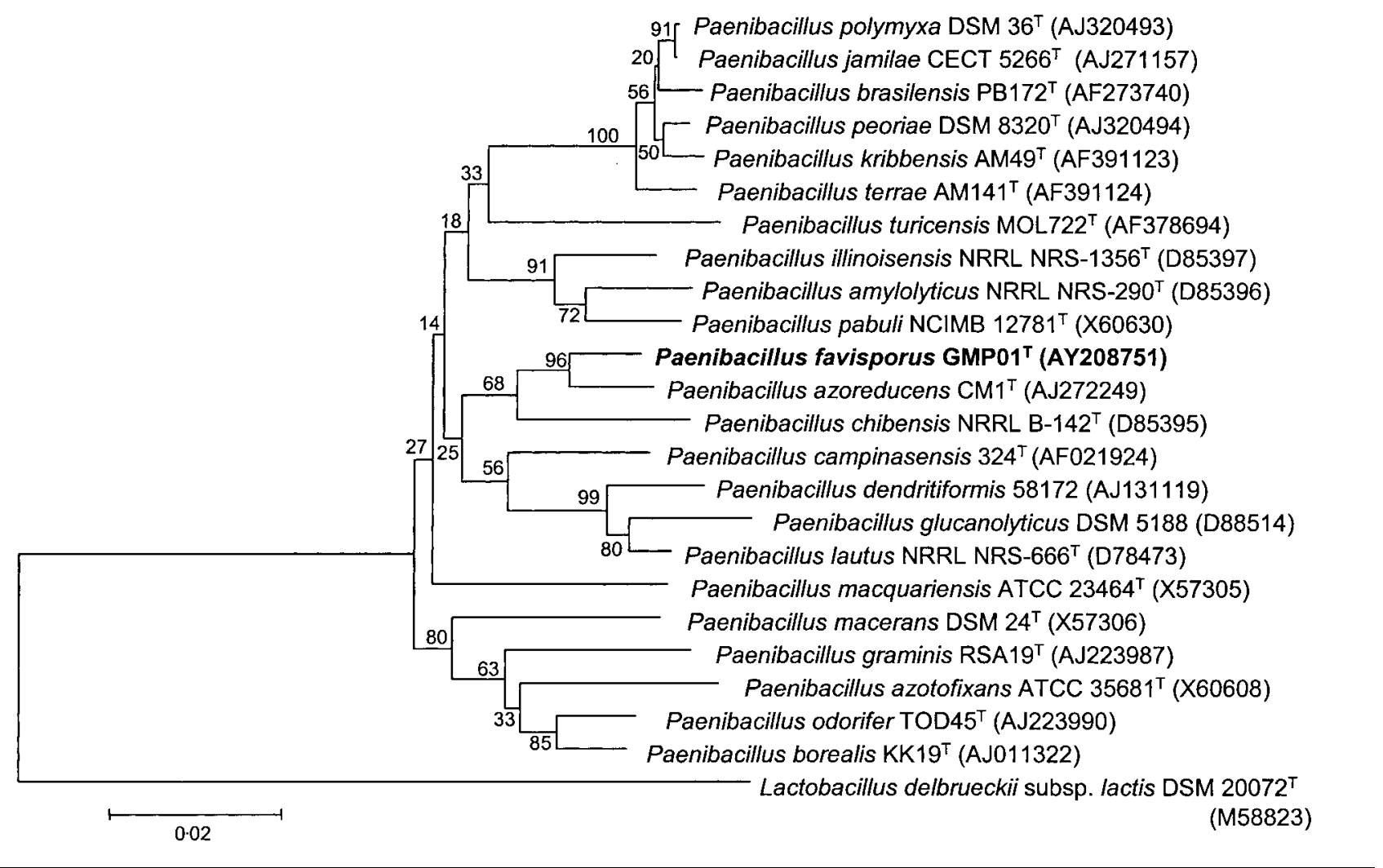

Fig. 1. Comparative sequence analysis of $16 \mathrm{~S}$ rDNA from Paenibacillus favisporus $\mathrm{GMP} 01^{\top}$ and representative strains of the genus Paenibacillus from GenBank, using the neighbour-joining method. Significance of each branch is indicated by a bootstrap value calculated for 1000 subsets. Bar, 2 nt substitutions per 100 nt.

DNA was isolated by following the method of Marmur (1961). G + C content was determined by hydrolysing the DNA enzymically and quantifying the nucleosides by HPLC, as reported previously (Cerdà-Cuéllar et al., 1997). Pooled standard deviation (SD) of the experiment was $0 \cdot 5$. The DNA G + C content of strain GMP01 ${ }^{\mathrm{T}}$ was $53 \mathrm{~mol} \%$. This value is similar to that obtained for $P$. azoreducens (Meehan et al., 2001).

DNA was isolated by chromatography on hydroxyapatite by the procedure of Cashion et al. (1977). DNA-DNA hybridization was carried out as described by De Ley et al. (1970), with the modifications described by Huss et al. (1983) and Escara \& Hutton (1980). The results of DNADNA hybridization showed $100 \%$ relatedness between strains $\mathrm{GMP}^{\mathrm{T}}{ }^{\mathrm{T}}$ and GMP02 and $17 \cdot 1 \%$ between strain $\mathrm{GMP}^{\mathrm{T}}{ }^{\mathrm{T}}$ and $P$. azoreducens DSM $13822^{\mathrm{T}}$. These results indicate that strain $\mathrm{GMP} 01^{\mathrm{T}}$ does not belong to $P$. azoreducens, when the recommended threshold value of $70 \%$ DNA-DNA similarity for definition of species is considered (Wayne et al., 1987).

Therefore, on the basis of phylogenetic, chemotaxonomic and phenotypic data, we propose that isolate $\mathrm{GMP} 01^{\mathrm{T}}$ $\left(=\mathrm{LMG} 20987^{\mathrm{T}}=\right.$ CECT $5760^{\mathrm{T}}$ ) should be classified as the type strain of a novel species, Paenibacillus favisporus sp. nov.

\section{Description of Paenibacillus favisporus sp. nov.}

Paenibacillus favisporus (fa.vi.spo'rus. L. n. favus a honeycomb; Gr. n. spora a seed, spore; N.L. masc. adj. favisporus referring to the honeycomb form of spores).

Gram-variable, motile, aerobic or facultatively anaerobic, chemo-organotrophic, xylanolytic bacteria. Colonies on YED medium are circular, convex, white with a central brown spot, translucent and usually $1-3 \mathrm{~mm}$ in diameter within $48 \mathrm{~h}$ at $37^{\circ} \mathrm{C}$. Optimal growth temperature is $37^{\circ} \mathrm{C}$; optimal growth $\mathrm{pH}$ is 7 . Oxidase- and catalase-positive. Spore-forming rods, $2-3 \mu \mathrm{m}$ long and $0 \cdot 5-0 \cdot 7 \mu \mathrm{m}$ wide. Spores slightly swell the sporangia and they are in subterminal position in cells. Spores have a ornamentation similar to that of honeycomb. This species is phylogenetically most closely related to $P$. azoreducens. DNA G $+\mathrm{C}$ content of the type strain is $53 \mathrm{~mol} \%$. The main fatty acid is anteiso-branched $\mathrm{C}_{15: 0}$. Gas is not produced from D-glucose. Acid is produced from D-glucose, sucrose, D-mannose, lactose, raffinose, rhamnose, melibiose, maltose, xylose and mannitol. Xylan, CM-cellulose and starch are utilized as carbon sources. By contrast, no growth occurs in L-arabinose, citrate, inositol, sorbitol, glucitol or xylitol as carbon sources. Xylanases, cellulases, gelatinase, urease, amylase and $\beta$-galactosidase are produced actively, but 
Table 1. Distinctive phenotypic characteristics of species phylogenetically related to Paenibacillus favisporus sp. nov.

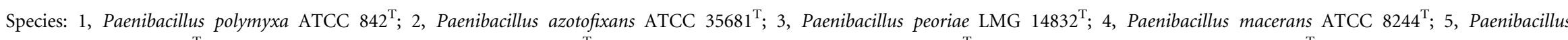

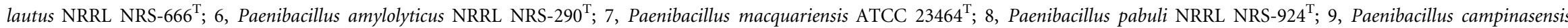

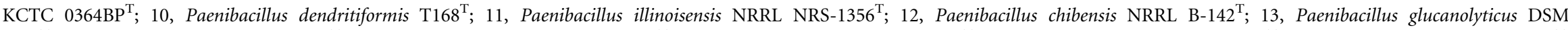

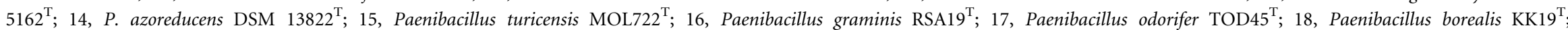

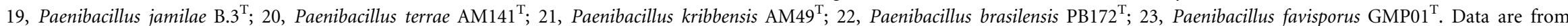
Meehan et al. (2001) except where indicated. +, Positive; -, negative; V, variable; W, weak; NR, not recorded.

\begin{tabular}{|c|c|c|c|c|c|c|c|c|c|c|c|c|c|c|c|c|c|c|c|c|c|c|c|}
\hline Test & 1 & 2 & 3 & 4 & 5 & 6 & 7 & 8 & 9 & 10 & 11 & 12 & 13 & 14 & $15^{\star}$ & $16 \dagger$ & $17 \dagger$ & $18 \ddagger$ & $19 \S$ & $20 \|$ & $21 \|$ & 229 & 23 \\
\hline Anaerobic growth & + & + & + & + & + & + & + & + & + & + & + & - & + & + & + & + & + & + & + & + & + & + & + \\
\hline Optimum growth temp. & 30 & $30-37$ & 30 & 30 & $28-30$ & $28-30$ & 20 & $28-30$ & 40 & 37 & 37 & 37 & NR & 37 & $37-42$ & $10-35$ & $5-35$ & 28 & 30 & 30 & $30-37$ & $30-32$ & 37 \\
\hline Catalase & + & + & + & + & + & + & + & + & + & + & + & + & NR & + & - & + & + & + & + & + & + & + & + \\
\hline Oxidase & - & - & - & NR & - & - & NR & - & - & + & - & - & + & - & - & - & - & - & - & - & - & NR & + \\
\hline Nitrate reduction & + & - & + & + & + & + & - & - & NR & - & - & + & $\mathrm{V}$ & - & - & + & + & - & + & + & + & + & + \\
\hline \multicolumn{24}{|l|}{ Production of: } \\
\hline Acetylmethylcarbinol & + & + & + & - & - & - & - & - & NR & - & - & - & NR & - & + & NR & NR & - & + & $\mathrm{NR}$ & NR & + & - \\
\hline Indole & - & - & - & - & - & - & - & - & NR & + & NR & - & NR & - & - & NR & NR & - & $\mathrm{NR}$ & $\mathrm{NR}$ & NR & NR & - \\
\hline Dihydroxyacetone & + & - & - & - & NR & NR & - & NR & NR & - & NR & - & NR & - & NR & NR & NR & - & $\mathrm{NR}$ & $\mathrm{NR}$ & NR & - & - \\
\hline $\mathrm{pH}$ in $\mathrm{V}-\mathrm{P}$ broth\# & $4 \cdot 5-6 \cdot 8$ & $4 \cdot 5-5 \cdot 1$ & $5 \cdot 5-6 \cdot 6$ & $4 \cdot 5-5 \cdot 0$ & $<5 \cdot 5$ & $<5 \cdot 5$ & $<6$ & $<5 \cdot 5$ & NR & $<6$ & $5 \cdot 0-5 \cdot 2$ & $4 \cdot 6-4 \cdot 7$ & NR & $4 \cdot 6-4 \cdot 7$ & NR & NR & NR & $\mathrm{NR}$ & $\mathrm{NR}$ & $\mathrm{NR}$ & NR & NR & $5 \cdot 0$ \\
\hline Tyrosinase & - & - & - & - & - & - & - & - & NR & - & - & - & NR & - & NR & NR & NR & $\mathrm{NR}$ & $\mathrm{NR}$ & - & - & NR & - \\
\hline Caseinase & + & - & + & - & - & - & - & $\mathrm{V}$ & + & + & + & - & $\mathrm{V}$ & - & NR & - & NR & + & + & + & + & + & - \\
\hline Amylases & + & - & + & + & + & + & + & + & + & + & + & + & NR & + & NR & + & + & - & + & + & + & + & + \\
\hline Citrate & - & - & + & V & - & - & - & - & NR & - & - & - & $\mathrm{V}$ & - & - & - & NR & - & - & $\mathrm{W}$ & $\mathrm{W}$ & + & - \\
\hline \multicolumn{24}{|l|}{ Growth at/in: } \\
\hline $\mathrm{pH} 5 \cdot 6$ & + & + & + & + & - & + & - & + & - & + & + & + & + & + & + & NR & NR & + & + & + & + & + & + \\
\hline $50^{\circ} \mathrm{C}$ & - & - & - & + & - & - & - & - & - & - & + & + & NR & + & - & - & - & - & $\mathrm{NR}$ & - & - & - & - \\
\hline $5 \% \mathrm{NaCl}$ & - & - & - & - & + & - & - & $\mathrm{V}$ & + & + & - & - & + & - & + & NR & NR & - & - & - & - & - & $\mathrm{w}$ \\
\hline \multicolumn{24}{|l|}{ Utilization of: } \\
\hline L-Arabinose & + & - & + & + & + & + & - & + & + & - & + & + & $\mathrm{v}$ & - & + & + & + & + & + & + & - & - & - \\
\hline Mannitol & + & + & + & + & + & + & + & + & - & - & + & + & NR & + & - & + & - & $\mathrm{V}$ & + & + & + & + & + \\
\hline D-Xylose & + & - & + & + & + & + & + & + & + & - & + & + & NR & + & + & + & + & + & + & + & - & - & + \\
\hline
\end{tabular}

${ }^{\star}$ Bosshard et al. (2002).

†Berge et al. (2002).

\$lo et al. (2001).

\$Aguilera et al. (2001).

IIYoon et al. (2003).

Svon der Weid et al. (2002).

\#V-P broth, Voges-Proskauer broth. 
Table 2. Cellular fatty acid composition of strain $\mathrm{GMPO} 1^{\top}$ and phylogenetically related species of the genus Paenibacilllus

Species: 1, Paenibacillus favisporus $\mathrm{GMP}^{\mathrm{T}}{ }^{\mathrm{T}}$; 2, P. azoreducens; 3, P. chibensis; 4, P. illinoisensis; 5, P. macquariensis. Data from Meehan et al. (2001).

\begin{tabular}{|lrrrrr|}
\hline Fatty acid & $\mathbf{1}$ & $\mathbf{2}$ & $\mathbf{3}$ & $\mathbf{4}$ & \multicolumn{1}{c|}{$\mathbf{5}$} \\
\hline Straight-chain: & & & & & \\
$\quad \mathrm{C}_{10: 0}$ & $1 \cdot 2$ & $3 \cdot 5$ & $0 \cdot 3$ & $2 \cdot 0$ & $0 \cdot 7$ \\
$\mathrm{C}_{15: 0}$ & $3 \cdot 6$ & $0 \cdot 1$ & $0 \cdot 6$ & $1 \cdot 0$ & $1 \cdot 2$ \\
$\mathrm{C}_{16: 0}$ & $8 \cdot 7$ & $22 \cdot 1$ & $5 \cdot 3$ & $24 \cdot 7$ & $2 \cdot 9$ \\
Iso-branched: & & & & & \\
$\quad \mathrm{C}_{14: 0}$ & $0 \cdot 9$ & $0 \cdot 8$ & $0 \cdot 8$ & $1 \cdot 8$ & $0 \cdot 8$ \\
$\mathrm{C}_{15: 0}$ & $6 \cdot 5$ & $5 \cdot 9$ & $4 \cdot 0$ & $1 \cdot 5$ & $5 \cdot 2$ \\
$\mathrm{C}_{16: 0}$ & $11 \cdot 1$ & $8 \cdot 6$ & $12 \cdot 2$ & $6 \cdot 3$ & $2 \cdot 6$ \\
Anteiso-branched: & & & & & \\
$\mathrm{C}_{17: 0}$ & $3 \cdot 3$ & $5 \cdot 6$ & $3 \cdot 2$ & $1 \cdot 4$ & $0 \cdot 4$ \\
$\mathrm{C}_{15: 0}$ & $48 \cdot 8$ & $33 \cdot 9$ & $57 \cdot 8$ & $56 \cdot 6$ & $81 \cdot 0$ \\
$\mathrm{C}_{17: 0}$ & $15 \cdot 0$ & $19 \cdot 8$ & $14 \cdot 3$ & $4 \cdot 9$ & $0 \cdot 7$ \\
\hline
\end{tabular}

caseinase, phenylalanine deaminase, lysine decarboxylase, tyrosinase, indole, dihydroxyacetone, hydrogen sulfide, acetylmethylcarbinol and acetoin (Voges-Proskauer medium) are not produced. Nitrate is reduced to nitrite. Susceptible to erythromycin, penicillin, oxacillin, bacitracin, piperacillin, gentamicin and cefoxitin; resistant to tobramicin, cephalexin and dibekacin.

The type strain, GMP01 ${ }^{\mathrm{T}}\left(=\mathrm{LMG} 20987^{\mathrm{T}}=\mathrm{CECT} 5760^{\mathrm{T}}\right)$, was isolated from old cow dung in Salamanca, Spain.

\section{Acknowledgements}

This work was supported by Spanish Government grants to E.V., R. R.-M. and T. G. V. We are grateful to C. Belinchón and F. Alonso for their help with electron microscopy preparations. We are also grateful to Dr Kroppenstedt and Dr Schumann (DSMZ) for their help with fatty acid methyl ester and DNA-DNA homology analyses, respectively.

\section{References}

Aguilera, M., Monteoliva-Sánchez, M., Suárez, A., Guerra, V., Lizama, C., Bennasar, A. \& Ramos-Cormenzana, A. (2001). Paenibacillus jamilae sp. nov., an exopolysaccharide-producing bacterium able to grow in olive-mill wastewater. Int J Syst Evol Microbiol 51, 1687-1692.

Annison, G. (1992). Commercial enzyme supplementation of wheatbased diets raises ileal glycanase activities and improves apparent metabolisable energy, starch and pentosan digestibilities in broiler chickens. Anim Feed Sci Technol 38, 105-121.

Ash, C., Priest, F. G. \& Collins, M. D. (1994). Paenibacillus gen. nov. In Validation of the Publication of New Names and New Combinations Previously Effectively Published Outside the IJSB, List no. 51. Int J Syst Bacteriol 44, 852.

Aÿ, J., Götz, F., Borriss, R. \& Heinemann, U. (1998). Structure and function of the Bacillus hybrid enzyme GluXyn-1: native-like jellyroll fold preserved after insertion of autonomous globular domain. Proc Natl Acad Sci U S A 95, 6613-6618.
Beg, Q. K., Bhushan, B., Kapoor, M. \& Hoondal, G. S. (2000). Production and characterization of thermostable xylanase and pectinase from Streptomyces sp. QG-11-3. J Ind Microbiol Biotechnol 24, 396-402.

Berge, O., Guinebretière, M.-H., Achouak, W., Normand, P. \& Heulin, T. (2002). Paenibacillus graminis sp. nov. and Paenibacillus odorifer sp. nov., isolated from plant roots, soil and food. Int J Syst Evol Microbiol 52, 607-616.

Bosshard, P. P., Zbinden, R. \& Altwegg, M. (2002). Paenibacillus turicensis sp. nov., a novel bacterium harbouring heterogeneities between 16S rRNA genes. Int J Syst Evol Microbiol 52, 2241-2249.

Busch, J. E. \& Stutzenberger, F. J. (1997). Xylanase biosynthesis in Thermomonospora curvata is not repressed by glucose. Bioresour Technol 60, 81-85.

Cashion, P., Holder-Franklin, M. A., McCully, J. \& Franklin, M. (1977). A rapid method for the base ratio determination of bacterial DNA. Anal Biochem 81, 461-466.

Cerdà-Cuéllar, M., Rosselló-Mora, R. A., Lalucat, J., Jofre, J. \& Blanch, A. (1997). Vibrio scophthalmi sp. nov., a new species from turbot (Scophthalmus maximus). Int J Syst Bacteriol 47, 58-61.

Chamberlain, K. \& Crawford, D. L. (2000). Thatch biodegradation and antifungal activities of two lignocellulolytic Streptomyces strains in laboratory cultures and in golf green turfgrass. Can J Microbiol 46, $550-558$.

Claus, D. \& Berkeley, R. C. W. (1986). Genus Bacillus Cohn 1872, $174^{\mathrm{AL}}$. In Bergey's Manual of Systematic Bacteriology, vol. 2, pp. 1105-1139. Edited by P. H. A. Sneath, N. S. Mair, M. E. Sharpe \& J. G. Holt. Baltimore: Williams \& Wilkins.

De Ley, J., Cattoir, H. \& Reynaerts, A. (1970). The quantitative measurement of DNA hybridization from renaturation rates. Eur $J$ Biochem 12, 133-142.

Doetsch, R. N. (1981). Determinative methods of light microscopy. In Manual of Methods for General Bacteriology, pp. 21-33. Edited by P. Gerdhardt, R. G. E. Murray, R. N. Costilow, E. W. Nester, W. A. Wood, N. R. Krieg \& G. B. Phillips. Washington, DC: American Society for Microbiology.

Elo, S., Suominen, I., Kämpfer, P., Juhanoja, J., SalkinojaSalonen, M. \& Haahtela, K. (2001). Paenibacillus borealis sp. nov., a nitrogen-fixing species isolated from spruce forest humus in Finland. Int J Syst Evol Microbiol 51, 535-545.

Escara, J. F. \& Hutton, J. R. (1980). Thermal stability and renaturation of DNA in dimethyl sulfoxide solutions: acceleration of the renaturation rate. Biopolymers 19, 1315-1327.

Esteban, R., Chordi, A. \& Villa, T. G. (1983). Some aspects of a 1,4- $\beta$ $D$-xylanase and $\beta$-D-xylosidase secreted by Bacillus coagulans strain 26. FEMS Microbiol Lett 17, 163-166.

Hespell, R. B. (1996). Fermentation of xylan, corn fiber, or sugars to acetoin and butanediol by Bacillus polymyxa strains. Curr Microbiol 32, 291-296.

Huss, V. A. R., Festl, H. \& Schleifer, K.-H. (1983). Studies on the spectrophotometric determination of DNA hybridization from renaturation rates. Syst Appl Microbiol 4, 184-192.

Kimura, M. (1980). A simple method for estimating evolutionary rates of base substitutions through comparative studies of nucleotide sequences. J Mol Evol 16, 111-120.

Kumar, S., Tamura, K., Jakobsen, I. B. \& Nei, M. (2001). MEGA2: molecular evolutionary genetic analysis software. Bioinformatics 17, 1244-1245.

Lamed, R., Bayer, E., Saha, B. C. \& Zeikus, J. G. (1988). Biotechnological potential of enzyme from unique thermophiles. In Proceedings of the 8th International Biotechnology Symposium, 
pp. 371-383. Edited by G. Durand, L. Bobichon and J. Florent. Paris: French Society for Microbiology.

Lee, H. J., Shin, D. J., Cho, N. C., Kim, H. O., Shin, S. Y., Im, S. Y., Lee, H. B., Chun, S. B. \& Bai, S. (2000). Cloning, expression and nucleotide sequences of two xylanase genes from Paenibacillus sp. Biotechnol Lett 22, 387-392.

Logan, N. A. \& Berkeley, R. C. W. (1984). Identification of Bacillus strains using the API system. J Gen Microbiol 130, 1871-1882.

Maat, J., Roza, M., Verbakel, J. \& 9 other authors (1992). Xylanases and their application in bakery. In Xylans and Xylanases (Progress in Biotechnology no. 7), pp. 349-360. Edited by J. Visser, M. A. Kusters van Someren, G. Beldman and A. G. J. Voragen. Amsterdam: Elsevier.

Marmur, J. (1961). A procedure for the isolation of deoxyribonucleic acid from microorganisms. J Mol Biol 3, 208-218.

Meehan, C., Bjourson, A. J. \& McMullan, G. (2001). Paenibacillus azoreducens sp. nov., a synthetic azo dye decolorizing bacterium from industrial wastewater. Int J Syst Evol Microbiol 51, 1681-1685.

Morales, P., Madarro, A., Flors, A., Sendra, J. M. \& Pérez-González, J. A. (1995). Purification and characterization of a xylanase and an arabinofuranosidase from Bacillus polymyxa. Enzyme Microb Technol 17, 424-429.

Nielsen, P. \& Sorensen, J. (1997). Multi-target and mediumindependent fungal antagonism by hydrolytic enzymes in Paenibacillus polymyxa and Bacillus pumilus strains from barley rhizosphere. FEMS Microbiol Ecol 22, 183-192.

Nishimoto, M., Honda, Y., Kitaoka, M. \& Hayashi, K. (2002). A kinetic study on $\mathrm{pH}$-activity relationship of XynA from alkaliphilic Bacillus halodurans C-125 using aryl-xylobiosides. J Biosci Bioeng 93, 428-430.

Pearson, W. \& Lipman, D. (1988). Improved tools for biological sequence comparison. Proc Natl Acad Sci U S A 85, 2444-2448.

Puchart, V., Katapodis, P., Biely, P., Kremnicky, L., Christakopoulos, P., Vrsanska, M., Kekos, D., Macris, B. J. \& Bhat, M. K. (1999). Production of xylanases, mannanases, and pectinases by the thermophilic fungus Thermomyces lanuginosus. Enzyme Microb Technol 24, 355-361.

Reynolds, E. S. (1963). The use of lead citrate at high $\mathrm{pH}$ as an electron-opaque stain in electron microscopy. J Cell Biol 17, 208-212.

Rivas, R., Velázquez, E., Valverde, A., Mateos, P. F. \& MartínezMolina, E. (2001). A two primers random amplified polymorphic DNA procedure to obtain polymerase chain reaction fingerprints of bacterial species. Electrophoresis 22, 1086-1089.

Rivas, R., Sánchez, M., Trujillo, M. E., Zurdo-Piñeiro, J. L., Mateos, P. F., Martínez-Molina, E. \& Velázquez, E. (2003a). Xylanimonas cellulosilytica gen. nov., sp. nov., a xylanolytic bacterium isolated from a decayed tree (Ulmus nigra). Int J Syst Evol Microbiol 53, 99-103.

Rivas, R., Willems, A., Subba-Rao, N. S., Mateos, P. F., Dazzo, F. B., Kroppenstedt, R. M., Martínez-Molina, E., Gillis, M. \& Velázquez, E. (2003b). Description of Devosia neptuniae sp. nov. that nodulates and fixes nitrogen in symbiosis with Neptunia natans, an aquatic legume from India. Syst Appl Microbiol 26, 47-53.

Ruiz-Arribas, A., Fernández-Abalos, J. M., Sánchez, P., Garda, A. L. \& Santamaría, R. I. (1995). Overproduction, purification, and biochemical characterization of a xylanase (Xys1) from Streptomyces halstedii JM8. Appl Environ Microbiol 61, 2414-2419.

Sá-Pereira, P., Mesquita, A., Duarte, J. C., Barros, M. R. A. \& CostaFerreira, M. (2002). Rapid production of thermostable cellulase-free xylanase by a strain of Bacillus subtilis and its properties. Enzyme Microb Technol 30, 924-933.

Saitou, N. \& Nei, M. (1987). The neighbor-joining method: a new method for reconstructing phylogenetic trees. Mol Biol Evol 4, 406-425.

Tabernero, C., Sánchez-Torres, J., Pérez, P. \& Santamaría, R. I. (1995). Cloning and DNA sequencing of $x y a A$, a gene encoding an endo- $\beta$-1,4-xylanase from an alkalophilic Bacillus strain (N137). Appl Environ Microbiol 61, 2420-2424.

Thompson, J. D., Gibson, T. J., Plewniak, F., Jeanmougin, F. \& Higgins, D. G. (1997). The CLUSTAL_X windows interface: flexible strategies for multiple sequence alignment aided by quality analysis tools. Nucleic Acids Res 25, 4876-4882.

Tseng, M. J., Yap, M. N., Ratanakhanokchai, K., Kyu, K. L. \& Chen, S. T. (2002). Purification and characterization of two cellulase free xylanases from an alkaliphilic Bacillus firmus. Enzyme Microb Technol 30, 590-595.

Viikari, L., Kantelinen, A., Sundquist, J. \& Linko, M. (1994). Xylanases in bleaching: from an idea to the industry. FEMS Microbiol Rev 13, 335-350.

von der Weid, I., Frois Duarte, G., van Elsas, J. D. \& Seldin, L. (2002). Paenibacillus brasilensis sp. nov., a novel nitrogen-fixing species isolated from the maize rhizosphere in Brazil. Int J Syst Evol Microbiol 52, 2147-2153.

Wayne, L. G., Brenner, D. J., Colwell, R. R. \& 9 other authors (1987). International Committee on Systematic Bacteriology. Report of the ad hoc committee on reconciliation of approaches to bacterial systematics. Int J Syst Bacteriol 37, 463-464.

Yoon, J.-H., Oh, H.-M., Yoon, B.-D., Kang, K. H. \& Park, Y.-H. (2003). Paenibacillus kribbensis sp. nov. and Paenibacillus terrae sp. nov., bioflocculants for efficient harvesting of algal cells. Int J Syst Evol Microbiol 53, 295-301.

Zamost, B. L., Nielsen, H. K. \& Starnes, R. L. (1991). Thermostable enzymes for industrial applications. J Ind Microbiol 8, 71-82. 